\section{Recommendations for folate intake in women: implications for public health strategies}

\author{
Recomendações para ingestão de folato por \\ mulheres: implicações para as estratégias \\ de saúde pública
}

\author{
${ }^{1}$ Faculdade de Saúde \\ Pública, Universidade de São \\ Paulo, São Paulo, Brasil. \\ Correspondence \\ M. A. Cardoso \\ Departamento de Nutrição, \\ Faculdade de Saúde Pública \\ Universidade de São Paulo. \\ Av. Dr. Arnaldo 715, São Paulo, \\ SP 01246-904, Brasil. \\ marlyac@usp.br
}

\begin{abstract}
Folate deficiency has been associated with anemia and other adverse outcomes in pregnancy such as neural tube defects. The current recommendations for prevention of such outcomes are difficult to achieve through diet only, and folic acid supplementation and food fortification are feasible public health strategies. However, it is necessary to determine the usual diet and supplement use among women of reproductive age, including an accurate assessment of other dietary micronutrients. In addition to the beneficial effects observed in randomized clinical trials, health risks to the population have also been widely evaluated and discussed in the scientific community: for a minority to benefit from fortification programs, many are exposed to high folic acid intake levels.

Folic Acids; Pteroylpolyglutamic Acids; Nutritional Epidemiology
\end{abstract}

Lana Carneiro Almeida 1 Marly Augusto Cardoso ${ }^{1}$

\section{Introduction}

Data released by the World Health Organization (WHO) show that women of reproductive age, along with infants younger than 2 years of age, are at their nutritionally most vulnerable stage in life 1 . In contrast to trends in developed countries over the past 70 years, high rates of maternal morbidity and mortality persist in developing regions, particularly among low-income women. Maternal mortality figures differ greatly between wealthy and poor nations, with the later accounting for $90 \%$ of such deaths 2 . Around 160 million women become pregnant ever year, approximately $15 \%$ of whom develop serious preventable complications, and millions of newborns do not survive the first week of life due to the absence or lack of proper prenatal healthcare ${ }^{3}$.

One of the indirect complications contributing to maternal health (and consequently to infant health) is maternal anemia. Anemia is especially common among women of reproductive age secondary to menstrual bleeding and to physiological changes during pregnancy 4 , yet remains prevalent owing to limited availability of diagnostic and treatment services.

From a nutritional standpoint, deficiencies in iron, vitamins B12, A and folate cause hematologic changes which if untreated can evolve to an anemic state 5 . Folic acid has been a focus of research for the past 30 years given its role in the 
prevention of another condition: neural tube closure defects.

The role of folic acid in biochemical reactions, such as those involved in metabolism of aminoacids and in the synthesis of DNA, renders it a critical nutrient in embryogenesis. During embryogenesis closure of the neural tube, the structure from which the brain and spinal column are derived, takes place 6 . Neural tube closure defects can lead to death of the infant or to serious life-long complications. There is evidence for a protective effect against these defects through pre and periconceptional folate supplementation 7 .

Folic acid supplementation in women was therefore introduced to address two principal problems: maternal anemia and neural tube closure defects. In view of limited adherence to supplementation however, food fortification was subsequently proposed for prevention of neural tube closure defects. The aim of the present study was to consider both these outcomes by analyzing and summarizing the recommendations and conducts pertaining to consumption of this vitamin in light of the latest scientific evidence.

\section{Definitions and background}

Although the umbrella term "folic acid" has been adopted in this article to denote all forms of the vitamin, including those found in plasma and erythrocytes, there are key differences between folate (occurring naturally in foods) and oxidized folic acid (synthetic form used in supplements and fortified foods). Folate is in the form of polyglutamates (pteroylpolyglutamate) whereas folic acid is in monoglutamate (pteroylmonoglutamate) form. Polyglutamates have higher metabolic activity and are better retained by cells, while monoglutamates pass through cell walls more rapidly. In humans, the metabolism of polyglutamates requires their deconjugation to monoglutamates within enterocytes, explaining their low bioavailability $(\sim 50 \%)$ compared to monoglutamates ( 85\%) 8. Moreover, anti-folate components present in vegetables as well as exposure to heat and light during cooking and storage, all contribute to lowering folate availability 9 .

Differences in bioavailability hamper the establishing of recommendations. To adjust for the bioavailability differences between folate and folic acid, Dietary Folate Equivalents (DFE) are used. The DFE assumes that the bioavailability of folic acid added to foods is 1.7-fold greater than that of natural folate (mathematically, DFE $=$ folate $+1.7 \mathrm{x}$ folic acid) 10 . An individual's folate acid status therefore depends on the source of the vi- tamin in the diet as well as the absolute amount consumed.

Folic acid supplementation was primarily indicated for the prevention and treatment of megaloblastic and maternal anemia 11. Supplementation is also indicated in individuals with a genetic defect requiring greater amounts of folate than can be derived from the diet 12 . Based on evidence that folic acid also prevents neural tube closure defects 13 , supplementation in public health programs was recommended, particularly since, unlike megaloblastic anemia, sera concentrations of folic acid in mothers of children with neural tube defects were normal 14. Against this background, the present article discusses the importance of recommendations of folic acid in public health programmes for the prevention and control of two different outcomes, namely: anemia during pregnancy and neural tube closure defects.

\section{Anemia during pregnancy}

Around one million maternal and infant lives are cut short every year due to anemia, a condition associated to low birth weight, prematurity and neonatal mortality, and a cause of disablement, mental retardation and compromised work performance 15 .

Anemia has multiple causes including blood loss, parasitic infections, cancer, hemoglobinopathies, malaria and deficiencies in nutrients such as iron, vitamins B12, A, riboflavin and folic acid 15 . The contributions of nutritional factors to the etiology of anemia can vary according to age, physiological state and socio-economic conditions, such that interpretation of a specific marker in isolation is not valid in scenarios where the etiology of anemia may be more complex.

The WHO considers anemia a global publichealth problem: a significant proportion of women of reproductive age (29.6\%) live in countries where anemia is a serious health problem (anemia prevalence $\geq 40 \%$ ), and over half the global population of pre-school children $(56.3 \%)$ and pregnant women $(57.5 \%)$ reside in such countries, the majority of which are located in Africa, Asia and Latin America 16. Studies on the prevalence of folic acid deficiency and also on the hematological response to folic acid in Brazil are scarce 17 . According to Metz 18, anemia due to folic acid deficiency in developed countries is rare, but still occurs in developing countries, especially in areas endemic for malaria and with a high incidence of iron deficiency anemia, hemoglobinopathies and HIV.

Population-based data for Brazil reveals that the occurrence of anemia among women of re- 
productive age (10-49 years) ranges from $15.2 \%$ (rural zone of Pernambuco) to $26.2 \%$ (Piaui), and from $14.7 \%$ (Rio de Janeiro) to $40.4 \%$ (Recife, Pernambuco) among pregnant women ${ }^{19}$. In São Leopoldo, Rio Grande do Sul, a transversal study on a representative sample of 312 women (20-60 years) found an overall prevalence of $19.2 \%$, and double this rate among negro women (54\%) 20 . There is a lack of representative data for other regions in Brazil for the past ten years estimating the magnitude of the problem in women of reproductive age.

The Department of Nutrition for Health and Development of the WHO summarized the current recommendations for creating and implementing public health intervention programmes 21 . Weekly iron-folic acid supplementation, in synchrony with enterocyte turnover, was proposed as an equally effective preventive measure as daily supplementation in publichealth programmes, and a more optimal approach given its lower side-effects and ease of administration in community settings 22 . It is important that an assessment is carried our prior to commencing interventions and once running, programmes should be monitored on a monthly basis to check processes and outcomes throughout the first year, and then verified every five years thereafter.

In Brazil, the goal of the National Programme of Supplementation with Iron, proposed by the General Coordination of Food and Nutrition Policy (CGPAN), is to reduce the prevalence of anemia in infants aged 6-18 months, in pregnant women and women after child birth or miscarriage 23. This is the first Brazilian programme of its kind to consider both supplementation with iron and provision of folic acid to target groups: $5 \mathrm{mg} /$ day of the vitamin administered from the 20th week of pregnancy up until childbirth. According to the guidelines of the Institute of Medicine, the recommended dose to prevent anemia in pregnant women is $0.4 \mathrm{mg} /$ day of folic acid (diet + supplement) 24 , with a maximum safe dose of $1 \mathrm{mg} /$ day 10 . Given the known and unknown adverse effects of over-supplementation with this vitamin, further studies reassessing this programme are needed.

Table 1 contains the recommendations for iron and folic acid supplementation in women for anemia prevention.

\section{Neural tube closure defects}

The neural tube normally closes within four weeks of conception or two weeks after interruption of menstruation. Cases of neural tube closure defect can lead to the pregnancies ending in miscarriage, stillbirth or in a child who may experience life-long medical complications 25 . Genetic, nutritional and environmental factors, or a combination of these, play a definitive role in the development of these conditions.

\section{- Genetics}

Blom et al. 26 proposed the theory of methylation, according to which problems in the methylation of lipids, DNA and protein during embryogenesis translate to a higher risk for neural tube defects in individuals with specific mutations. The enzyme 5,10-methylenetetrahydrofolate reductase (MTHFR) catalyzes the irreversible reduction of 5,10-methylenetetrahydrofolate to 5-methylenetetrahydrofolate, a methyl donor for biosynthesis of methionine and nucleotides. Mutations in MTHFR have been associated to greater risk of neural tube defects in some populations 27 yet not in others 28 . Other genes may influence the methylation cycle either through remethylation (MTR, MTRR, BHMT and BHMT2) or by transsulfuration (CBS) of homocysteine, compromising methylation and increasing homocysteine concentrations which are in turn associated to greater risk of neural tube defects 29 . A second hypothesis centers on the genes codifying to enzymes needed for nucleotide biosynthesis: there is evidence that a polymorphism in methylenetetrahydrofolate dehydrogenase (MTHFD1) is associated with a higher risk of neural tube defects in Italian 30, but not English 31, populations. The third theory concerns the genes codifying proteins involved in the transport, capture and cell retention of folate, such as the reduced folate carrier (RFC), folyl-gamma-glutamate carboxypeptidase (GCP2) and folylpolyglutamate synthase (FPGS), although not all studies have confirmed neural tube defect risk 32 .

\section{- Nutrition}

After the identification of folic acid as an important vitamin in the occurrence/reoccurrence of neural tube defects 33 , numerous studies ensued assessing associations between diet and neural tube defects. Folic acid acts as a donor of methyl groups in the synthesis of DNA, and the relationship between folic acid deficiency and neural tube defects may be linked to lower gene expression, given that methylation of DNA influences transcription and genomic stability 34 . Genenutrient interaction has been observed in recent studies: the effect of the mutant homozygosis of the MTHFR C677T polymorphism on homocysteine concentrations, a risk factor for neural tube defect, was reduced by moderate daily in- 
Table 1

Recommendations for iron and folic acid supplementation in women for prevention of anemia.

\begin{tabular}{|c|c|c|c|c|c|c|c|}
\hline Target population & Nutrient & Product & Dose & Frequency & Start & Duration & Source \\
\hline Women of reproductive & Iron & Iron sulfate & $60 \mathrm{mg}$ & $1 \mathrm{x} /$ week & 3 months prior & 3 months & WHO 21 \\
\hline age * & Folic acid ** & $\begin{array}{l}\text { Pteroylmono- } \\
\text { glutamate acid }\end{array}$ & 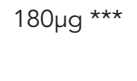 & 1x/day & to conception & & loM 24 \\
\hline \multirow[t]{2}{*}{ Pregnant women } & Iron & Iron sulfate & $60 \mathrm{mg} \#$ & $1 x /$ day & $\begin{array}{l}20^{\text {th }} \text { week of } \\
\text { pregnancy }\end{array}$ & $\begin{array}{l}\text { Up to } 3 \text { months } \\
\text { post-partum }\end{array}$ & WHO 21 \\
\hline & Folic acid & $\begin{array}{l}\text { Pteroylmono- } \\
\text { glutamate acid }\end{array}$ & $0.4 \mathrm{mg} * * *$ & & $\begin{array}{l}\text { 1st month of } \\
\text { pregnancy \#\# }\end{array}$ & $\begin{array}{l}\text { Until end of } \\
\text { pregnancy }\end{array}$ & loM 24 \\
\hline Women after birth or & Iron & Iron sulfate & $60 \mathrm{mg}$ & $1 x /$ day & Immediately & 3 months & WHO 21 \\
\hline miscarriage & Folic acid & $\begin{array}{l}\text { Pteroylmono- } \\
\text { glutamate acid }\end{array}$ & $0.4 \mathrm{mg}$ *** & & after birth & & \\
\hline
\end{tabular}

loM: Institute of Medicine; WHO: World Health Organization.

* In population groups where the prevalence of anemia is greater than $20 \%$ among women of reproductive age, weekly supplementation should be considered as a strategy for preventing iron deficiency, improving pre-pregnancy iron reserves and improving folate status in some women. In the absence of anemia data for this group, the prevalence of anemia (> 40\%) in other groups can be used as proxy: pregnant women or children aged $<5$ years. In the absence of this data, criteria such as dietary and socio-economic patterns may be employed 21;

** Supplementation with folic acid in this group may not be required in two situations: within regions where food fortification has proven effective; and in regions endemic for malaria where anti-folate treatment is employed, since evidence suggests that supplementation with folic acid may reduce the efficacy of these drugs 21;

$\star \star \star$ Diet + supplement;

\# Studies show that low daily doses of iron $(30 \mathrm{mg})$ during pregnancy improves maternal iron status and appears sufficient to protect the child from iron-deficiency anemia 10;

\#\# No collateral effects have been reported as a result of supplementation with folic acid from start of pregnancy.

take of folic acid 35 . It is noteworthy that neural tube defects constitute only one of the many problems linked to folic acid deficiency, since the vitamin is implicated in the etiology of other congenital anomalies such as Down's syndrome ${ }^{36}$, cleft lip and palate defects 37 .

\section{- Environment}

A low level of maternal education 38 and food shortage 39 have been identified as possible risk factors for neural tube defects, in addition to the use of medications which interfere with the metabolism of folic acid (anti-epileptics, aspirin, methotrexate, sulfasalazine etc.), hyperthermia, use of tobacco and excessive doses of vitamin A (> 15,000IU) during pregnancy 40 . The presence of abdominal obesity, diabetes mellitus and dyslipidemia may increase risk six-fold ${ }^{41}$, while obesity alone almost doubles the risk of neural tube defects 42 .

Technical advances in ultra-sonography providing more enhanced resolutions, together with the interruption of affected pregnancies, food fortification and intake of supplements containing folic acid, have substantially reduced the global prevalence of neural tube defects over the last three decades. These defects have an incidence of 1-2/1,000 births, varying with race and geographic region 40 both within and between countries. Worldwide, an estimated 240,000 cases of spina bifida and anencephaly, the most common forms of neural tube defects, occur annually 43 .

The role of folic acid deficiency in pregnancy complications, such as higher rates of miscarriage and fetal malformation, was first studied in the 1960s 44 , but the vitamin's role in preventing neural tube defects was only identified in the 1980 s and 1990s 13. Since this discovery, the consumption of folic acid-fortified foods and supplements have been recommended periconceptually in all American women of child-bearing age $(0.4 \mathrm{mg} /$ day to prevent a first occurrence of neural tube defect; $4 \mathrm{mg}$ /day to prevent a recurrence), in addition to a healthy diet 45 . A recent systematic review indicated that periconceptional supplementation with folic acid alone had a protective effect of $72 \%$ against neural tube defects, but may influence multiple births 7 .

In developing countries, the majority of pregnancies are unplanned 46 , and this has been cited as the main stumbling block in implementing 
recommendations to take folic acid for the prevention of neural tube defects. The disappointing results of public-health campaigns aimed at increasing the use of supplements 47 led to mandatory fortification of foods as an optimal solution to reach women in early stages of pregnancy. Over 50 countries, including Brazil, now fortify foods using folic acid 48 , sparking worldwide debate on its benefits and risks.

In Brazil, congenital defects have a significant impact on infant morbidity and mortality, and constitute the second most frequent cause of infant death (13\%) in the first year of life 49 . The cited study highlights the governmental and nongovernmental actions in the country, evidencing the urgent need for a specific policy aimed at the support, treatment and prevention of congenital defects which, in the current context, hinge more on good planning than on technology.

The recommendations for folic acid supplementation in women for the prevention of neural tube defects are summarized in Table 2.

\section{Use of synthetic folic acid}

\section{Supplementation}

Ray et al. 50 reviewed the prevalence of folic acid supplementation in community programmes worldwide and found a variation of $0.9 \%$ (Southern Israel) to $49 \%$ (Vancouver, Canada) during the preconception period and $0.5 \%$ (Sicily, Italy) to $52 \%$ (Holland) during the periconceptional period. In the United Kingdom, the leading factor underlying low adherence was unintentional pregnancies, followed by the young age of mothers, low income and Hispanic ethnicity 51. In Korea, a prevalence of periconceptional folic acid supplement use of $10.3 \%$ was observed, and was associated to a history of spontaneous miscarriage, planned pregnancy and knowledge of the benefits of folic acid 52 . Although the use of dietary supplements by pregnant and nursing American women has been little studied, data from the 1999-2000 National Health Nutrition Survey (NHANES) 53 showed that $52 \%$ of American adults took dietary supplements.

Knowledge on prevalence of folic acid supplement use during pregnancy in Brazil is scarce. A population-based transversal study (Pelotas, Rio Grande do Sul) reported a prevalence of folic acid supplement use during pregnancy of $31.8 \%$ versus $4.3 \%$ in the periconceptional period 54 .

Many studies are available investigating the positive link between folic acid supplement use and improved nutritional status of the vitamin among women ${ }^{55}$. A random uncontrolled clinical trial $(n=40)$ was conducted comparing erythrocyte folic acid concentrations in women who were not pregnant (18-45 years) after supplementation with $1.1 \mathrm{mg}$ or $5 \mathrm{mg} /$ day of folic acid for 30 weeks. The results concluded that the $5 \mathrm{mg}$ group had significantly higher erythrocyte folate

Recommendations for folic acid supplementation in women for prevention of neural tube defects.

\begin{tabular}{|c|c|c|c|c|c|c|c|}
\hline Target population & Nutrient & Product & Dose * & Frequency & Start & Duration & Source \\
\hline \multirow{11}{*}{$\begin{array}{l}\text { Women of reproductive } \\
\text { age } \star \star\end{array}$} & Folic acid & Pteroylmono- & $0.4 \mathrm{mg}$ & 1x/day & 3 months & 6 months & WHO 21 \\
\hline & & glutamate & (if no previous & & prior to & & \\
\hline & & acid & pregnancy & & conception & & \\
\hline & & & affected by neural & & & & \\
\hline & & & tube defect);or & & & & \\
\hline & & & $2.8 \mathrm{mg}$ & 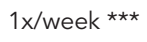 & & & \\
\hline & & & $4.0 \mathrm{mg}$ & $1 x /$ day & & & \\
\hline & & & (if a previous & & & & \\
\hline & & & pregnancy was & & & & \\
\hline & & & affected by neural & & & & \\
\hline & & & tube defect) & & & & \\
\hline
\end{tabular}

WHO: World Health Organization.

* Supplement, in addition to that provided by the diet;

** Because closure of the neural tube takes place by the 28th post-conception day, supplementation to prevent neural tube defects will only have an effect if started during the periconceptional period; however, this dose is still recommended by WHO specialists even after onset of pregnancy 3 ;

$\star \star \star$ Weekly supplementation is an option only for women of reproductive age; after becoming pregnant, the WHO recommends daily supplementation as listed above 21 . 
concentrations than the $1.1 \mathrm{mg}$ group at study endpoint 56 . The authors adopted a cut-off point of $906 \mathrm{nmol} / \mathrm{L}$ of erythrocyte folate as protective against neural tube defects, although failed to point out that the group supplemented with $1.1 \mathrm{mg}$ attained steady state erythrocyte folate concentrations $(1,625 \pm 339 \mathrm{nmol} / \mathrm{L})$ at levels $80 \%$ greater than the cut-off point. The cited study was funded by a pharmaceutical company.

Users of the supplement tend to take higherthan-recommended doses. A pharmacoepidemiological study in pregnant users of pre-natal primary care services in the city of Piracicaba, São Paulo, found that $47.9 \%$ of prescriptions were above the recommended daily dose 57 .

\section{Fortification}

According to estimates by Bell \& Oakley Jr. 58, 27\% of the world population has access to flour fortified with iron and/or folic acid. Fortification with folic acid produced positive results in the United States 59 , Canada 60 and Chile 61 , reducing the frequency of neural tube defects. Other possible impacts of this policy are emerging, some potentially beneficial such as lower plasma homocysteine levels 62 , and some harmful. Investigations carried out in the last decade have suggested that excessive intake of synthetic folic acid may promote the progression of undiagnosed neoplastic lesions, as seen with aberrant methylation of DNA in colorectal carcinogenesis 63, and has been linked to recurrent early pregnancy loss 64 , vitamin B12 deficiency 65 and multiple births 66 .

The Medical Research Council Vitamin Study (MRC), a random double-blind controlled clinical trial was a reference study for the establishment of the recommendation of $0.4 \mathrm{mg} /$ day of folic acid in women of reproductive age, leading to an estimated decrease in the incidence of neural tube defects of around $70 \% 13$. It is important to note however that the MRC sample comprised women who had previous pregnancies affected by neural tube defects and also that the placebo group was not "pure" (having taken iron and calcium pills). A study 67 assessing the relationship between folic acid supplementation and its sera levels (involving clinical trials which used folic acid doses > 1mg/day) and the effect of folic acid levels on the occurrence of neural tube defects (based on results from a cohort of 56,000 pregnant women) found that for a $0.4 \mathrm{mg} /$ day increase in folic acid intake, the reduction in risk for neural tube defects depended on the initial sera concentration of the vitamin, where the higher the initial concentrations, the lower the preventive effect. Moreover, for a given increase in folic acid intake, the sera concentrations of the vitamin increased more in older individuals than in younger ones 67 . Thus, it is questionable whether the recommended $0.4 \mathrm{mg} /$ day of folic acid for preventing neural tube defect applies to all population groups.

With regard to fortification, the quantity of

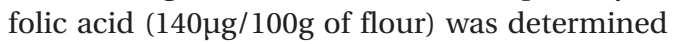
with the intention of providing an additional average intake of $100 \mu \mathrm{g} /$ day, while preventing daily intake from exceeding $1 \mathrm{mg} /$ day in American adults. Nevertheless, later studies showed that fortification in the United States was supplying more than twice the mandated amount 68 . Some months after fortification, reductions in folic acid deficiency were observed along with lower rates of hyperhomocysteinemia in the American general population, as well as a fall in the incidence of neural tube defects69. In parallel, the frequency of high blood folate concentrations (> 20ng/L) also rose among children and the elderly from $5 \%$ and $7 \%$ to $42 \%$ and $38 \%$, respectively 70 . After a period of overexposure to folic acid however, the intake of the vitamin was found to dip in American women of reproductive age, supposedly due to the popularity of low carbohydrate diets with consequent reduced levels of fortification. This phenomenon may explain the decrease in sera and erythrocyte folate concentrations seen in the NHANES survey from 1999-2004 71, suggesting that the effect of fortification on the risk of neural tube defects may be lower first assumed.

Studies on data from the Framingham Offspring Cohort showed that fortification more than doubled serum folate and increased erythrocyte folate by $30 \%$, and led to a $50 \%$ reduction in the prevalence of high homocysteine. In Australia, a population-based study found a $38 \%$ increase in serum folate and a $21 \%$ decrease in average homocysteine concentration 72 .

Fortification in Canada has led to an estimated reduction in prevalence of open neural tube defects of $50 \% 73$ to $70 \% 74$. Molloy et al. 75 argued that increased levels of fortification in these areas are unlikely to further reduce the prevalence of neural tube defects, and it is therefore necessary to identify other modifiable risk factors such as inadequate vitamin B12 status.

The Brazilian government introduced mandatory fortification of wheat and maize flour

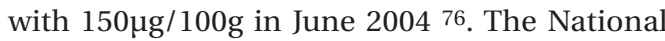
Institute of Metrology, Normalization and Industrial Quality (INMETRO) analyzed six brands of corn flour (3 sourced from Paraná state, 2 from Rio de Janeiro and 1 from Minas Gerais) and all conformed to the minimum quantity required by law 77 . Soeiro et al. 78 assessed folic acid in samples of five brands of wheat flour and three brands of corn flour in the city of Campinas, São 
Paulo: $12 \%$ (wheat) and $21 \%$ (corn) of the samples tested contained the quantity recommended by law, $60 \%$ (wheat) and $21 \%$ (corn) were low in folic acid, while $28 \%$ (wheat) and $58 \%$ (corn) exceeded mandated levels. Although these findings are important, there is currently a lack and need of national data quantifying folic acid in these flours and their derivatives.

To date, no population-based studies have been conducted assessing the impact of flour fortification with folic acid on the prevalence of neural tube defects in Brazil. A longitudinal study using data from the National System of Live Births (SINASC) from 2000 to $2006(\mathrm{n}=161,341)$ carried out in Recife found no statistically significant difference between prevalence of neural tube defects during pre-fortification $(0.75: 1,000$ live births) and post-fortification (0.51:1,000 live births) periods 79 . Preliminary data are available for other South American countries from the Latin-American Collaboration Study on Congenital Malformations (ECLAMC) for the period spanning from 1999 to 2001 80. Among countries included in the survey, only Chile, where fortification levels have been $220 \mu \mathrm{g} / 100 \mathrm{~g}$ of flour since 2000 , showed a statistically significant reduction in rates of neural tube defects, although the authors did not rule out the possibility of "ecological fallacy".

The process of implementing fortification programmes in some countries, particularly in Europe, has been guided by comprehensive appraisal plans for monitoring the effectiveness and safety of the interventions. In Ireland for example, after accepting the recommendation of the National Committee on Folic Acid Food Fortification in 2006, the government charged a group of specialists to perform a preparatory study prior to implementing the programme for mandatory fortification of bread. Key indicators for assessing the future effects of higher folic acid intake by the population were studied: prevalence and incidence of pregnancies affected by neural tube defects; estimate of the degree of voluntary fortification with folic acid; blood folic acid status among subgroups of the population 81 .

According to a guidelines published by the WHO 82, implementation of a food fortification programme entails the following steps: (1) determination of the nutritional status of the population with regard to the nutrient in question; (2) election of a suitable food vehicle; (3) establishment of the acceptability and stability of the fortified vehicle; (4) assessment of the bioavailability of the nutrient in the chosen vehicle; (5) conducting of a controlled field study and; (6) implementation of a regional or national fortification programme.
In Brazil's case, with regard to adherence to the steps outlined above, there have been insufficient studies assessing whether all age groups, or regions of the country have benefited from fortification (step 1). Table 3 contains a calculation of folic acid consumption based on estimates of food expenditure drawn from the Brazilian Household Budget Survey (HBS) 83, based on the assumption that fortification in Brazil takes place as stipulated by law $(150 \mu \mathrm{g} / 100 \mathrm{~g}$ flour). Values approach those expected for the United States, of around $100 \mu \mathrm{g} /$ day from fortification, yet it is pertinent to ask: What is the distribution of the folic acid deficiency across different regions of Brazil? Which age/physiological groups benefit from fortification? Do these groups consume wheat or corn flour? Is any specific group at risk?

In fact, the lack of nationally representative data on folic acid status is a problem common to other countries worldwide. A recent review 17 revealed that only ten countries (Costa Rica, France, Germany, Mexico, New Zealand, Norway, Switzerland, England, the United States and Venezuela) conduct surveys on folic acid status among the national population, although data generally relates to specific age or physiological groups thereby precluding extrapolation.

The decision to elect wheat and corn flour as the vehicles for folic acid in Brazil (step 2) was based on the premise that these foods are widely consumed by the Brazilian population. These flours however, constitute ingredients of processed foods such as cakes and biscuits (creams or otherwise) which are sources of nutrients known to be harmful to health, including simple carbohydrates and saturated and trans fats. Manufacturers of these products exploit the fortification factor as a selling point in their marketing strategy.

With regard to step 3, international studies have demonstrated that folic acid in flour was organoleptically well accepted, given that its stability was not significantly changed 84 . It was found that the addition of folic acid, as well as other nutrients, at different levels of fortification, had only a marginal effect 85 .

In terms of the bioavailability of folic acid in vehicles chosen (step 4), amounts up to $0.5 \mathrm{mg}$ / $\mathrm{kg}$ of wheat or corn flour yielded bioavailability of over $85 \% 86$.

Community surveys (step 5) should be conducted in order to assess potential risks and efficacy of fortification across different regions in Brazil. Despite the absence of these studies, the fortification programme went ahead in Brazil. 
Table 3

Average folic acid (FA) intake in Brazil based on estimated food expenditure from the 2002-2003 Brazilian Household Budget Survey (HBS) 83.

\begin{tabular}{|c|c|c|c|c|c|c|c|}
\hline \multirow[t]{2}{*}{ Food item } & \multirow{2}{*}{$\begin{array}{c}\text { FA or folate } \\
\text { content } \\
\text { (ug)/100g } \\
\text { flour or } \\
\text { natural source }\end{array}$} & \multicolumn{2}{|c|}{ All regions } & \multicolumn{2}{|c|}{ North } & \multicolumn{2}{|c|}{ Northeast } \\
\hline & & $\begin{array}{l}\text { Daily dietary } \\
\text { intake per } \\
\text { capita (g) }\end{array}$ & $\begin{array}{l}\text { Estimated } \\
\text { FA or folate } \\
\text { intake }(\mu \mathrm{g}) / \\
\text { day }\end{array}$ & $\begin{array}{l}\text { Daily dietary } \\
\text { intake per } \\
\text { capita (g) }\end{array}$ & $\begin{array}{l}\text { Estimated } \\
\text { FA or folate } \\
\text { intake }(\mu \mathrm{g}) / \\
\text { day }\end{array}$ & $\begin{array}{l}\text { Daily dietary } \\
\text { intake per } \\
\text { capita (g) }\end{array}$ & $\begin{array}{c}\text { Estimated } \\
\text { FA or folate } \\
\text { intake }(\mu \mathrm{g}) / \\
\text { day }\end{array}$ \\
\hline Fortified foods & & & 128.07 & & 85.27 & & 128.19 \\
\hline Wheat flour & 150 & 13.93 & 20.90 & 5.91 & 8.87 & 4.07 & 6.11 \\
\hline Corn cream sauce & 150 & 0.50 & 0.75 & 0.17 & 0.25 & 1.55 & 2.33 \\
\hline Corn flakes & 150 & 1.03 & 1.55 & 0.37 & 0.55 & 2.12 & 3.18 \\
\hline Corn flour & 150 & 8.73 & 13.10 & 4.69 & 7.04 & 16.45 & 24.68 \\
\hline Pastry * (70\% wheat flour) & 150 & 9.17 & 13.76 & 5.98 & 8.97 & 9.02 & 13.53 \\
\hline Bread * (80\% wheat flour) & 150 & 44.49 & 66.74 & 34.56 & 51.84 & 43.44 & 65.16 \\
\hline Cakes * (50\% wheat flour) & 150 & 0.95 & 1.43 & 0.31 & 0.47 & 0.62 & 0.92 \\
\hline Biscuits * (50\% wheat flour) & 150 & 6.58 & 9.87 & 4.85 & 7.27 & 8.18 & 12.27 \\
\hline Natural sources & & & 10.18 & & 7.45 & & 14.34 \\
\hline Boiled spinach & 146 & 0.43 & 0.63 & 0.07 & 0.11 & 0.61 & 0.88 \\
\hline Cow's liver & 253 & 1.17 & 2.96 & 1.49 & 3.76 & 1.54 & 3.90 \\
\hline Cooked beans & 48 & 4.32 & 2.07 & 2.13 & 1.02 & 14.64 & 7.03 \\
\hline Raw beetroot & 109 & 1.15 & 1.25 & 0.82 & 0.89 & 0.68 & 0.74 \\
\hline Boiled broccoli & 108 & 0.30 & 0.32 & 0.02 & 0.02 & 0.01 & 0.01 \\
\hline Iceberg lettuce & 29 & 1.76 & 0.51 & 1.72 & 0.50 & 1.15 & 0.33 \\
\hline Boiled cauliflower & 44 & 0.48 & 0.21 & 0.07 & 0.03 & 0.07 & 0.03 \\
\hline Oranges & 30 & 6.01 & 1.80 & 1.93 & 0.58 & 4.22 & 1.26 \\
\hline Boiled kale & 93 & 0.35 & 0.33 & 0.50 & 0.47 & 0.10 & 0.09 \\
\hline Cucumber with skin & 7 & 1.33 & 0.09 & 1.03 & 0.07 & 0.89 & 0.06 \\
\hline \multicolumn{8}{|l|}{ sources } \\
\hline \multirow[t]{2}{*}{ Food item } & \multicolumn{2}{|c|}{ Southeast } & \multicolumn{3}{|c|}{ South } & \multicolumn{2}{|c|}{ Mid-west } \\
\hline & $\begin{array}{l}\text { Daily dietary } \\
\text { intake per capita } \\
\text { (g) }\end{array}$ & $\begin{array}{c}\text { Estimated FA } \\
\text { or folate intake } \\
(\mu g) / \text { day }\end{array}$ & $\begin{array}{r}\text { Daily } \\
\text { intake } \mathrm{p}\end{array}$ & $\begin{array}{l}\text { tary } \\
\text { capita }\end{array}$ & $\begin{array}{l}\text { ted FA } \\
\text { e intake } \\
\text { /day }\end{array}$ & $\begin{array}{l}\text { Daily dietary } \\
\text { take per capita } \\
\text { (g) }\end{array}$ & $\begin{array}{c}\text { Estimated FA } \\
\text { or folate intake } \\
\qquad(\mu \mathrm{g}) / \text { day }\end{array}$ \\
\hline Fortified foods & & 123.89 & & & .50 & & 81.76 \\
\hline Wheat flour & 10.17 & 15.25 & & & 87 & 10.72 & 16.08 \\
\hline Corn cream sauce & 0.12 & 0.17 & & & 02 & 0.04 & 0.05 \\
\hline Corn flakes & 0.85 & 1.28 & & & 27 & 0.23 & 0.35 \\
\hline Corn flour & 5.87 & 8.81 & & & 20 & 2.45 & 3.68 \\
\hline Pastry * (70\% wheat flour) & 9.67 & 14.51 & & & .25 & 6.75 & 10.12 \\
\hline Bread * (80\% wheat flour) & 48.65 & 72.98 & & & .08 & 29.54 & 44.31 \\
\hline Cakes * $(50 \%$ wheat flour $)$ & 1.12 & 1.67 & & & 52 & 0.52 & 0.78 \\
\hline Biscuits * (50\% wheat flour) & 6.14 & 9.21 & & & .28 & 4.25 & 6.38 \\
\hline
\end{tabular}

(continues) 


\begin{tabular}{|c|c|c|c|c|c|c|}
\hline \multirow[t]{2}{*}{ Food item } & \multicolumn{2}{|c|}{ Southeast } & \multicolumn{2}{|c|}{ South } & \multicolumn{2}{|c|}{ Mid-west } \\
\hline & $\begin{array}{l}\text { Daily dietary } \\
\text { intake per capita } \\
\text { (g) }\end{array}$ & $\begin{array}{c}\text { Estimated FA } \\
\text { or folate intake } \\
(\mu \mathrm{g}) / \text { day }\end{array}$ & $\begin{array}{l}\text { Daily dietary } \\
\text { intake per capita } \\
\text { (g) }\end{array}$ & $\begin{array}{c}\text { Estimated FA } \\
\text { or folate intake } \\
(\mu \mathrm{g}) / \text { day }\end{array}$ & $\begin{array}{c}\text { Daily dietary } \\
\text { intake per capita } \\
\text { (g) }\end{array}$ & $\begin{array}{c}\text { Estimated FA } \\
\text { or folate intake } \\
(\mu \mathrm{g}) / \text { day }\end{array}$ \\
\hline Natural sources & & 8.97 & & 8.60 & & 7.21 \\
\hline Boiled spinach & 0.35 & 0.50 & 0.64 & 0.93 & 0.14 & 0.20 \\
\hline Cow's liver & 1.15 & 2.92 & 0.45 & 1.14 & 1.00 & 2.54 \\
\hline Cooked beans & 0.10 & 0.05 & 0.08 & 0.04 & 0.15 & 0.07 \\
\hline Raw beetroot & 1.21 & 1.32 & 1.63 & 1.78 & 1.95 & 2.13 \\
\hline Boiled broccoli & 0.54 & 0.58 & 0.42 & 0.45 & 0.04 & 0.04 \\
\hline Iceberg lettuce & 1.84 & 0.53 & 2.76 & 0.80 & 1.67 & 0.49 \\
\hline Boiled cauliflower & 0.78 & 0.34 & 0.68 & 0.30 & 0.29 & 0.13 \\
\hline Oranges & 7.98 & 2.39 & 6.82 & 2.04 & 4.02 & 1.21 \\
\hline Boiled kale & 0.26 & 0.24 & 1.02 & 0.95 & 0.32 & 0.30 \\
\hline Cucumber with skin & 1.27 & 0.09 & 2.37 & 0.17 & 1.50 & 0.10 \\
\hline $\begin{array}{l}\text { Fortified foods + natural } \\
\text { sources }\end{array}$ & & 132.86 & & 193.10 & & 88.97 \\
\hline
\end{tabular}

* Values in parentheses represent estimated average percentage of wheat or corn flour contained in the food.

\section{Adverse effects of synthetic folic acid}

The debate over fortification with folic acid, despite its success in reducing rates of neural tube defects in some countries, has intensified in recent years in light of several fresh theories and findings 87,88 .

A study on immune function in post-menopausal women found that activity of natural killer cells was influenced by intake of folic acid supplements $\geq 400 \mu \mathrm{g} /$ day. Natural killer activity is important in the defense against infection as well as in eliminating cancerous cells. This activity was reduced by $25 \%$ in women who consumed diets with adequate folate supplemented with folic acid. Moreover, unmetabolized folic acid was detected in the blood of $78 \%$ of women in this group 89 .

Kelly et al. 90, in an uncontrolled, random clinical trial, found levels of unmetabolized serum folic acid post-prandially in volunteers (1842 years) who consumed bread fortified with $266 \mu \mathrm{g}$ of folic acid/meal for five days. These authors pointed out that, depending on the levels of fortification, unmetabolized folic acid can persist in plasma for many years, particularly in individuals consuming large amounts of fortified foods. The authors also called for a review of the 1mg/day Tolerable Upper Level Intake (UL) of folic acid. Many women who adhere to the $400 \mu \mathrm{g} /$ day recommendation may present consistently high concentrations of unmetabolized folic acid in plasma. The saturation of dihydrofo- late reductase (DHFR), an enzyme which slowly converts folic acid into tetrahydrofolate for use by the organism, partially explains the build-up of unmetabolized folic acid in plasma, implying that benefits of consuming high doses of folic acid are indeed limited 91 .

Several mechanisms have been postulated as contributing to the risk of disease among individuals taking folic acid supplements and frequently manifesting unmetabolized folic acid in the bloodstream. One such effect is based on the fact that folic acid shares the same mechanisms of cell transport as MTHF in most tissues, meaning that high blood folic acid levels may compete for cellular transport with MTHF, needed for normal metabolic reactions. Studies have shown that gene expression of the cellular transporters decreases after incubation of human intestinal and renal cells with high concentrations of folic acid 92 . Another proposed mechanism is that high intracellular concentrations of folic acid may promote the synthesis and use of greater quantities of MTHF which, through its B12-dependent pathway for DNA synthesis, may deplete vitamin B12 needed for normal cognitive function 93 .

A number of studies have shown a relationship between use of folic acid supplementation and higher risk of cancer. A prospective, nineyear study involving more than 11,000 individuals in Sweden, a country without mandatory fortification, showed a lower incidence of breast cancer in women with high folic acid intake ${ }^{94}$. Another study in a cohort of over 25,000 post- 
highest quintile of folic acid intake, derived from both diet and supplements 95 . A prospective study in more than 1,000 men and women followed up for ten years after surgical resection for colorectal cancer found a $52 \%$ greater risk of recurrence of high-grade dysplastic adenomas in individuals taking folic acid supplements (10.9\%) compared with those taking placebo (4.3\%) 96 . Knowledge on the mechanisms by which folic acid stimulates the development of some types of cancer is explored in the process of devising anti-cancer drugs, which interfere in the functioning of enzymes metabolizing the vitamin 97 .

Genetic damage in the presence of synthetic folic acid have also been a focus of investigations. A controlled, double-blind, random clinical trial in 56 healthy male and female volunteers (20-60 years) observed a significant decrease in the incorporation of uracil ( $p<0.05$ ) in a supplemented group (1.2 mg folic acid) compared to a placebo group (glucose). Incorporation of uracil was more sensitive to folic acid status in healthy volunteers than other biomarkers of DNA damage 98 .

Through their metabolic interactions, folic acid and vitamin B12 protect the organism against anemia and cognitive decline. Vitamin $\mathrm{B} 12$ is needed for the functioning of methionine synthase, the enzyme responsible for remethylation of homocysteine to methionine and for converting N5-methylTHF to THF. In conditions of B12 deficiency, folic acid remains in N5-methylTHF form and N5, N10-methyleneTHF needed for DNA synthesis is not produced leading to erythrocyte macrocytosis. If the diet is supplemented with high doses of folic acid, macrocytosis secondary to vitamin B12 deficiency can be corrected since excess folic acid is converted into dihydrofolate (DHF) which is then converted into THF, restoring the process of normal DNA synthesis 99 . A study involving more than 1,500 elderly from the 1999-2002 NHANES survey found that low vitamin B12 status with normal folic acid status (20\% of group) doubled anemia risk to $7 \%$, while increasing dementia risk from $18 \%$ to $25 \%$. In addition, the incidences of anemia and dementia in individuals with low B12 status yet high folic acid status due to supplements use (3.3\% of group), increased significantly to $15 \%$ and $45 \%$, respectively 100 .

These studies are summarized in Table 4 .

\section{Final considerations}

The inclusion of family planning campaigns into the routine of public-health services could prevent the high number of cases of pregnancies in which the mother is unaware of conception, thus allowing commencement of supplementation prior to pregnancy and throughout maternity. This measure would not only prevent folic acid deficiency during the most critical period of embryogenesis but also avoid indiscriminate use of the supplement. Evidence has shown that, even in developed countries such as Japan, information on the role of periconceptional intake of folic acid is not sufficiently disseminated among young women 101. Improvements in maternal health and the provision of quality health services in the area of human reproduction constitute essential actions to eliminate the multiple causes underlying infant mortality.

From a nutritional standpoint, since folate is mainly found in fresh fruit and leafy vegetables, individuals who are deficient in the vitamin due to under-consumption of these foods can also present deficiency in other important nutrients. Thus, the incentive to consume fruit, legumes and vegetables, besides having no adverse effects, can yield greater health benefits. All health professionals involved in the contraceptive care of women can contribute by propagating this information, placing emphasis on the protective effects of a healthy diet, particularly of a folaterich diet.

Scientific evidence indicates that the strategy with the greatest impact in reducing the prevalence of maternal anemia and neural tube defects is supplementation aimed at target groups with close monitoring of treatment doses and duration. It is important to bear in mind that the benefits of fortification are clear, but that various adverse effects exist, and for every pregnancy with neural tube defect prevented, hun dreds of people may be exposed to high levels of folic acid intake. A cautious approach to implementing universal fortification policies has been urged since 1995 102. Many countries have opted against mandatory fortification, primarily because additional health benefits are not yet proven in clinical trials, secondly due to the unknown risks, and thirdly out of respect for individuals' freedom of choice 103 . 
Studies assessing adverse effects of excessive synthetic folic acid intake.

\begin{tabular}{|c|c|c|c|c|c|}
\hline Reference & Place/Year & Study design & $\begin{array}{l}\text { Characteristics } \\
\text { of population } \\
\text { ( } n / \text { age/ } \\
\text { physiological } \\
\text { status) }\end{array}$ & $\begin{array}{l}\text { Exposure (dose/ } \\
\text { duration/period) }\end{array}$ & Results/Adverse effects \\
\hline Troen et al. 89 & USA/2006 & $\begin{array}{l}\text { Transversal } \\
\text { (subsample of } \\
\text { population of } \\
\text { a study in the } \\
\text { greater Seattle } \\
\text { recruited for } \\
\text { an intervention } \\
\text { trial) }\end{array}$ & $\begin{array}{l}\text { Healthy } \\
\text { premenopausal } \\
\text { women } \\
(n=105)\end{array}$ & $\begin{array}{l}\text { Dietary intake } \\
\text { (measured by } \\
\text { food frequency } \\
\text { questionnaire) } \\
\text { and number of } \\
\text { supplement pills/ } \\
\text { day, in the year } \\
\text { preceding blood } \\
\text { collection }\end{array}$ & $\begin{array}{c}\text { Women with high folate intake ( }>233 \mu \mathrm{g} / \text { day) had lower } \\
\text { cytotoxicity of natural killer }(\mathrm{NK}) \text { cells if they also took folic } \\
\text { acid supplements ( }>400 \mu \mathrm{g})(\mathrm{p}=0.02) \text {. NK cells are part } \\
\text { of the specific immune response and can destroy a variety } \\
\text { of cells infected by virus and tumor cells, protecting } \\
\text { against cancer }\end{array}$ \\
\hline Kelly et al. 90 & Ireland/1997 & $\begin{array}{l}\text { Uncontrolled, } \\
\text { randomized, } \\
\text { clinical trial }\end{array}$ & $\begin{array}{l}\text { Healthy } \\
\text { volunteers (5 } \\
\text { men and } 18 \\
\text { women), aged } \\
18-42 \text { years }\end{array}$ & $\begin{array}{l}\text { Intake of bread } \\
\text { fortified with } \\
266 \mu \mathrm{g} \text { folic acid/ } \\
\text { meal, for } 5 \text { days }\end{array}$ & Presence of unmetabolized folic acid in plasma \\
\hline $\begin{array}{l}\text { Stolzenberg- } \\
\text { Solomon et al. } 95\end{array}$ & USA/2006 & Cohort & $\begin{array}{c}25,400 \\
\text { women (aged } \\
55-74 \text { years) } \\
\text { from Prostate, } \\
\text { Lung, } \\
\text { Colorectal } \\
\text { and Ovarian } \\
\text { Cancer } \\
\text { Screening } \\
\text { Trial }\end{array}$ & $\begin{array}{l}\text { Dietary intake } \\
\text { (measured by } \\
\text { food frequency } \\
\text { questionnaire) } \\
\text { and multivitamin } \\
\text { in the year } \\
\text { preceding blood } \\
\text { collection }\end{array}$ & $\begin{array}{l}\text { Adjusted RR were } 1.19(95 \% \mathrm{Cl}: 1.01 ; 1.41 ; \mathrm{p} \text { for trend } \\
=0.04) \text { for women reporting use of } 400 \mu \mathrm{g} / \text { day of folic } \\
\text { acid supplements compared with those reporting no } \\
\text { supplement use. Comparison between greatest and } \\
\text { lowest quintile yielded an adjusted RR of } 1.04(95 \% \mathrm{Cl} \text { : } \\
0.83 ; 1.31 ; \mathrm{p} \text { for trend }=0.56) \text { and } 1.32(95 \% \mathrm{Cl}: 1.04 ; \\
\begin{array}{c}1.68 ; \mathrm{p} \text { for trend }=0.03) \text { for intake of dietary folate and } \\
\text { total folate, respectively }\end{array}\end{array}$ \\
\hline Cole et al. 96 & USA/2007 & $\begin{array}{l}\text { Controlled, } \\
\text { double-blind, } \\
\text { randomized, } \\
\text { clinical trial }\end{array}$ & $\begin{array}{c}\text { 1,021 men } \\
\text { and women } \\
\text { (21-80 years) } \\
\text { with recent } \\
\text { history of } \\
\text { colorectal } \\
\text { adenomas } \\
\text { and no } \\
\text { previous } \\
\text { intestinal } \\
\text { carcinoma }\end{array}$ & $\begin{array}{c}\text { Intervention } \\
\text { group: } 1 \mathrm{mg} / \text { day } \\
\text { of folic acid } \\
\text { ( } \mathrm{n}=516) \text {, control } \\
\text { group: placebo } \\
\text { ( } \mathrm{n}=505) \\
\text { Both groups } \\
\text { were randomized } \\
\text { separately to } \\
\text { receive aspirin } \\
(81 \text { or } 325 \mathrm{mg} / \\
\text { day) or placebo }\end{array}$ & 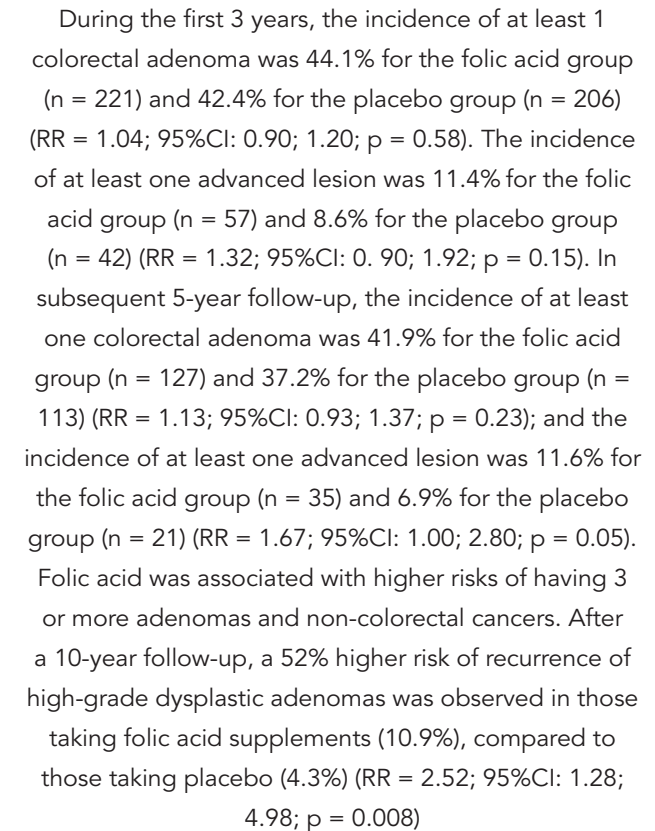 \\
\hline
\end{tabular}

(continues) 
Table 4 (continued)

\begin{tabular}{|c|c|c|c|c|c|}
\hline Reference & Place/Year & Study design & $\begin{array}{l}\text { Characteristics } \\
\text { of population } \\
\text { (n/age/ } \\
\text { physiological } \\
\text { status) }\end{array}$ & $\begin{array}{l}\text { Exposure (dose/ } \\
\text { duration/period) }\end{array}$ & Results/Adverse effects \\
\hline Basten et al. 98 & England/2006 & $\begin{array}{l}\text { Controlled, } \\
\text { double-blind, } \\
\text { randomized, } \\
\text { clinical trial }\end{array}$ & $\begin{array}{l}\text { Healthy male } \\
\text { and female } \\
\text { volunteers } \\
(\mathrm{n}=56) \text {, aged } \\
20-60 \text { years }\end{array}$ & $\begin{array}{l}\text { Intervention } \\
\text { group: } 1.2 \mathrm{mg} \\
\text { folic acid, control } \\
\text { group: glucose }\end{array}$ & $\begin{array}{l}\text { A significant decrease in incorporation of uracil } \\
\text { ( } p<0.05 \text { ) was observed in the supplemented group } \\
\text { compared with the placebo group. Incorporation of } \\
\text { uracil is more sensitive to folic acid status in healthy } \\
\text { individuals than other biomarkers of DNA damage }\end{array}$ \\
\hline Morris et al. 100 & USA/2007 & $\begin{array}{l}\text { Transversal } \\
\text { population- } \\
\text { based }\end{array}$ & $\begin{array}{l}\text { 1,459 elderly } \\
\text { ( } \geq 60 \text { years) } \\
\text { participants in } \\
\text { the National } \\
\text { Health and } \\
\text { Nutrition } \\
\text { Examination } \\
\text { Survey } \\
\text { (NHANES) }\end{array}$ & $\begin{array}{c}\text { Vitamin B12 } \\
\text { status and sera } \\
\text { methylmalonic } \\
\text { acid levels (MMA) } \\
\text { Low vitamin } \\
\text { B12 status was } \\
\text { defined as sera } \\
\text { vitamin B12 } \\
\text { concentrations } \\
<148 \rho \mathrm{mol} / \mathrm{L} \\
\text { or sera MMA } \\
\text { concentrations > } \\
210 \text { nmol/L }\end{array}$ & $\begin{array}{l}\text { In the group with low vitamin B12 status, sera folate } \\
>59 \mathrm{nmol} / \mathrm{L}(80 \text { th percentile), in contrast to sera folate } \\
=59 \mathrm{nmol} / \mathrm{L} \text {, was associated with anemia }(\mathrm{OR}=3.1 \text {; } \\
95 \% \mathrm{Cl} 1.5 ; 6.6) \text { and cognitive damage }(\mathrm{OR}=2.6 \text {; } \\
95 \% \mathrm{Cl}: 1.1 ; 6.1) \text {. In the group with normal } \mathrm{B} 12 \text { vitamin } \\
\text { status, the OR for high versus normal sera folate for } \\
\left.\text { these outcomes were }<1.0 \text { ( } \mathrm{p}_{\text {interaction }}<0.05\right) \text {, but } \\
\text { significantly }<1.0 \text { only for cognitive damage }(0.4 ; \\
95 \% \mathrm{Cl}: 0.2 ; 0.9)\end{array}$ \\
\hline
\end{tabular}

OR: odds ratio; RR: relative risk.

\section{Resumo}

A deficiência de ácido fólico tem sido associada ao risco de anemia e outros desfechos adversos na gravidez, como os defeitos no tubo neural. As recomendações atuais para prevenção de tais agravos são consideradas difíceis de se alcançar apenas por meio da dieta, e a suplementação com ácido fólico e a adição dessa vitamina a alimentos sob a forma de fortificação representam esforços centrais no controle da sua deficiência. É necessário, porém, conhecer as características da dieta habitual e o uso de suplementos entre mulheres em idade reprodutiva, com avaliação adequada de outros nutrientes da dieta. Ao lado dos efeitos benéficos observados em ensaios clínicos aleatórios controlados, riscos à saúde da população têm sido avaliados e largamente discutidos no meio científico: para que uma fração seja beneficiada pela fortificação, centenas de pessoas são expostas a quantidades de ácido fólico talvez elevadas e provavelmente incomuns, em quantidade e apresentação química, ao organismo humano.

Ácido Fólico; Ácidos Pteroilpoliglutâmicos; Epidemiologia Nutricional

\section{Contributors}

M. A. Cardoso planned and provided guidance on the organization of the study. L. C. Almeida carried out the literature search and produced the initial draft of the manuscript. L. C. Almeida and M. A. Cardoso reviewed the final version of the manuscript.

\section{Acknowledgments}

The authors would like to thank the São Paulo State Research Foundation (FAPESP) for providing financial support for this study (grant no. 2007/53043-8). L. C. Almeida holds a PhD grant from FAPESP (grant no. 2007/53044-4). 
1. World Health Organization. The World Health Report 2002. Reducing risks, promoting healthy life. Geneva: World Health Organization; 2002.

2. World Health Organization. Making a difference in countries: strategic approach to improving maternal and newborn survival and health. Geneva: World Health Organization; 2006.

3. World Health Organization. Women's health. Geneva: World Health Organization; 2001.

4. Subramoney S, Gupta PC. Anaemia in pregnancy. Indian J Med Res 2008; 128:780-1.

5. Jamil KM, Rahman AS, Bardhan PK, Khan AI, Chowdhury F, Sarker SA, et al. Micronutrients and anaemia. J Health Popul Nutr 2008; 26:340-55.

6. Tamura T, Picciano MF. Folate and human reproduction. Am J Clin Nutr 2006; 83:993-1016.

7. Lumley J, Watson L, Watson M, Bower C. Periconceptional supplementation with folate and/or multivitamins for preventing neural tube defects. Cochrane Database Syst Rev 2001; (3):CD001056.

8. Sanderson P, McNulty H, Mastroiacovo P, McDowell IF, Melse-Boonstra A, Finglas PM, et al. Folate bioavailability: UK Food Standards Agency Workshop Report. Br J Nutr 2003; 90:473-9.

9. McNulty H, Scott JM. Intake and status of folate and related B-vitamins: considerations and challenges in achieving optimal status. Br J Nutr 2008; 99 Suppl 3:S48-54.

10. Food and Nutrition Board, Institute of Medicine. DRI: dietary reference intakes for thiamin, riboflavin, niacin, vitamin $\mathrm{B} 6$, folate, vitamin $\mathrm{B} 12$, pantothenic acid, biotin, and choline. Washington DC: National Academy Press; 1998.

11. Smail SA. Dietary supplements in pregnancy. J R Coll Gen Pract 1981; 31:707-11.

12. Ashfield-Watt PA, Pullin CH, Whiting JM, Clark ZE, Moat SJ, Newcombe RG, et al. Methylenetetrahydrofolate reductase $677 \mathrm{C}-->\mathrm{T}$ genotype modulates homocysteine responses to a folate-rich diet or a low-dose folic acid supplement: a randomized controlled trial. Am J Clin Nutr 2002; 76:180-6.

13. MRC Vitamin Research Group. Prevention of neural tube defects: results of the Medical Research Council Vitamin Study. Lancet 1991; 338:131-7.

14. Selhub J, Rosenberg IH. Public health significance of supplementation or fortification of grain products with folic acid. Food Nutr Bull 2008; 29(2 Suppl):S173-6.

15. World Health Organization. Nutritional anemia. Geneva: World Health Organization; 2007.

16. World Health Organization. Global database on anaemia. Geneva: World Health Organization; 2008.

17. McLean E, de Benoist B, Allen LH. Review of the magnitude of folate and vitamin B12 deficiencies worldwide. Food Nutr Bull 2008; 29(2 Suppl):S38-51.

18. Metz J. A high prevalence of biochemical evidence of vitamin B12 or folate deficiency does not translate into a comparable prevalence of anemia. Food Nutr Bull 2008; 29(2 Suppl):S74-85.

19. Batista Filho M, Souza AI, Miglioli TC, Santos MC. Anemia e obesidade: um paradoxo da transição nutricional brasileira. Cad Saúde Pública 2008; 24 Suppl 2:S247-57.
20. Fabian C, Olinto MTA, Dias-da-Costa JS, Bairros F, Nácul LC. Prevalência de anemia e fatores associados em mulheres adultas residentes em São Leopoldo, Rio Grande do Sul, Brasil. Cad Saúde Pública 2007; 23:1199-205.

21. World Health Organization. Weekly Iron-Folic Acid Supplementation (WIFS) in women of reproductive age: its role in promoting optimal maternal and child health. Geneva: World Health Organization; 2009.

22. Pena-Rosas JP, Viteri FE. Effects of routine oral iron supplementation with or without folic acid for women during pregnancy. Cochrane Database Syst Rev 2006; (4):CD004736.

23. Coordenação-Geral da Política de Alimentação e Nutrição. Programa Nacional de Suplementação de Ferro: público a ser assistido e conduta de intervenção. http://nutricao.saude.gov.br/nutricao/ ferro_info_publico.php?exibe_pagina=ferro_pro grama_publico (accessed on 26/Aug/2008).

24. Food and Nutrition Board, Institute of Medicine. DRI: dietary reference intakes for thiamin, riboflavin, niacin, vitamin $\mathrm{B} 6$, folate, vitamin $\mathrm{B} 12$, pantothenic acid, biotin, and choline. Washington DC: National Academy Press; 1989.

25. Chen CP. Syndromes, disorders and maternal risk factors associated with neural tube defects (II). Taiwan J Obstet Gynecol 2008; 47:10-7.

26. Blom HJ, Shaw GM, den Heijer M, Finnell RH. Neural tube defects and folate: case far from closed. Nat Rev Neurosci 2006; 7:724-31.

27. Thomas P, Fenech M. Methylenetetrahydrofolate reductase, common polymorphisms, and relation to disease. Vitam Horm 2008; 79:375-92.

28. Boyles AL, Billups AV, Deak KL, Siegel DG, Mehltretter L, Slifer SH, et al. Neural tube defects and folate pathway genes: family-based association tests of gene-gene and gene-environment interactions. Environ Health Perspect 2006; 114:1547-52.

29. Boyles AL, Hammock P, Speer MC. Candidate gene analysis in human neural tube defects. Am J Med Genet C Semin Med Genet 2005; 135C:9-23.

30. De Marco P, Merello E, Calevo MG, Mascelli S, Raso A, Cama A, et al. Evaluation of a methylenetetrahydrofolate-dehydrogenase $1958 \mathrm{G}>\mathrm{A}$ polymorphism for neural tube defect risk. J Hum Genet 2006; 51:98-103.

31. Doudney K, Grinham J, Whittaker J, Lynch SA, Thompson D, Moore GE, et al. Evaluation of folate metabolism gene polymorphisms as risk factors for open and closed neural tube defects. Am J Med Genet A 2009; 149A:1585-9.

32. Beaudin AE, Stover PJ. Insights into metabolic mechanisms underlying folate-responsive neural tube defects: a minireview. Birth Defects Res A Clin Mol Teratol 2009; 85:274-84.

33. Welch AD. Folic acid: discovery and the exciting first decade. Perspect Biol Med 1983; 27:64-75. 
34. Zeisel SH. Importance of methyl donors during reproduction. Am J Clin Nutr 2009; 89:673S-7S.

35. Yang QH, Botto LD, Gallagher M, Friedman JM, Sanders CL, Koontz D, et al. Prevalence and effects of gene-gene and gene-nutrient interactions on serum folate and serum total homocysteine concentrations in the United States: findings from the third National Health and Nutrition Examination Survey DNA Bank. Am J Clin Nutr 2008; 88:232-46.

36. Patterson D. Folate metabolism and the risk of Down syndrome. Downs Syndr Res Pract 2008; 12:93-7.

37. Weingärtner J, Lotz K, Fanghänel J, Gedrange T, Bienengräber V, Proff P. Induction and prevention of cleft lip, alveolus and palate and neural tube defects with special consideration of B vitamins and the methylation cycle. J Orofac Orthop 2007; 68:266-77.

38. Grewal J, Carmichael SL, Song J, Shaw GM. Neural tube defects: an analysis of neighbourhood- and individual-level socio-economic characteristics. Paediatr Perinat Epidemiol 2009; 23:116-24.

39. Wynn A, Wynn M. The effects of food shortage on human reproduction. Nutr Health 1993; 9:43-52.

40. Chen CP. Syndromes, disorders and maternal risk factors associated with neural tube defects (IV). Taiwan J Obstet Gynecol 2008; 47:141-50.

41. Ford ES, Giles WH, Dietz WH. Prevalence of the metabolic syndrome among US adults: findings from the third National Health and Nutrition Examination Survey. JAMA 2002; 287:356-9.

42. Ray JG, Thompson MD, Vermeulen MJ, Meier C, Wyatt PR, Wong PY, et al. Metabolic syndrome features and risk of neural tube defects. BMC Pregnancy Childbirth 2007; 7:21.

43. Oakley Jr. GP, Johnston Jr. RB. Balancing benefits and harms in public health prevention programmes mandated by governments. BMJ 2004; 329:41-3.

44. Czeizel AE, Dudás I. Prevention of the first occurrence of neural-tube defects by periconceptional vitamin supplementation. N Engl J Med 1992; 327:1832-5.

45. Department of Health. Folic acid and the prevention of neural tube defects. Report from an Expert Advisory Committee. London: Department of Health; 1992.

46. Kramer MS. The epidemiology of adverse pregnancy outcomes: an overview. J Nutr 2003; 133(5 Suppl 2):1592S-6S.

47. van der Pal-de Bruin KM, de Walle HE, Jeeninga W, de Rover C, Cornel MC, de Jong-van den Berg LT, et al. The Dutch 'Folic Acid Campaign': have the goals been achieved? Paediatr Perinat Epidemiol 2000; 14:111-7.

48. Centers for Disease Control and Prevention. Trends in wheat-flour fortification with folic acid and iron: worldwide, 2004 and 2007. MMWR Morb Mortal Wkly Rep 2008; 57:8-10.

49. Horovitz DDG, Llerena Jr. JC, Mattos RA. Atenção aos defeitos congênitos no Brasil: panorama atual. Cad Saúde Pública 2005; 21:1055-64.

50. Ray JG, Singh G, Burrows RF. Evidence for suboptimal use of periconceptional folic acid supplements globally. BJOG 2004; 111:399-408.
51. Stockley L, Lund V. Use of folic acid supplements, particularly by low-income and young women: a series of systematic reviews to inform public health policy in the UK. Public Health Nutr 2008; 11:807-21.

52. Kim MH, Han JY, Cho YJ, Ahn HK, Kim JO, Ryu HM, et al. Factors associated with a positive intake of folic acid in the periconceptional period among Korean women. Public Health Nutr 2009; 12:468-71.

53. Radimer K, Bindewald B, Hughes J, Ervin B, Swanson C, Picciano MF. Dietary supplement use by US adults: data from the National Health and Nutrition Examination Survey, 1999-2000. Am J Epidemiol 2004; 160:339-49.

54. Mezzomo CL, Garcias GL, Sclowitz ML, Sclowitz IT, Brum CB, Fontana T, et al. Prevenção de defeitos do tubo neural: prevalência do uso da suplementação de ácido fólico e fatores associados em gestantes na cidade de Pelotas, Rio Grande do Sul, Brasil. Cad Saúde Pública 2007; 23:2716-26.

55. Botto LD, Moore CA, Khoury MJ, Erickson JD. Neural-tube defects. N Engl J Med 1999; 341:1509-19.

56. Nguyen P, Tam C, O'Connor DL, Kapur B, Koren G. Steady state folate concentrations achieved with 5 compared with $1.1 \mathrm{mg}$ folic acid supplementation among women of childbearing age. Am J Clin Nutr 2009; 89:844-52.

57. Carmo TA, Nitrini SM. Prescrições de medicamentos para gestantes: um estudo farmacoepidemiológico. Cad Saúde Pública 2004; 20:1004-13.

58. Bell KN, Oakley Jr. GP. Update on prevention of folic acid-preventable spina bifida and anencephaly. Birth Defects Res A Clin Mol Teratol 2009; 85:102-7.

59. Boulet SL, Yang Q, Mai C, Kirby RS, Collins JS, Robbins JM, et al. Trends in the postfortification prevalence of spina bifida and anencephaly in the United States. Birth Defects Res A Clin Mol Teratol 2008; 82:527-32.

60. Godwin KA, Sibbald B, Bedard T, Kuzeljevic B, Lowry RB, Arbour L. Changes in frequencies of select congenital anomalies since the onset of folic acid fortification in a Canadian birth defect registry. Can J Public Health 2008; 99:271-5.

61. Nazer J, Cifuentes L, Aguila A, Juárez ME, Cid MP, Godoy ML, et al. Efecto de la fortificación de la harina con ácido fólico sobre la evolución de las tasas de prevalencia al nacimiento de malformaciones congénitas en los hospitales chilenos del ECLAMC. Rev Méd Chile 2007; 135:198-204.

62. Hoey L, McNulty H, Askin N, Dunne A, Ward M, Pentieva K, et al. Effect of a voluntary food fortification policy on folate, related B vitamin status, and homocysteine in healthy adults. Am J Clin Nutr 2007; 86:1405-13.

63. Kim YI. Folate and colorectal cancer: an evidencebased critical review. Mol Nutr Food Res 2007; 51:267-92.

64. Nelen WL, Blom HJ, Steegers EA, den Heijer M, Thomas CM, Eskes TK. Homocysteine and folate levels as risk factors for recurrent early pregnancy loss. Obstet Gynecol 2000; 95:519-24. 
65. Hirsch S, de la Maza P, Barrera G, Gattás V, Petermann M, Bunout D. The Chilean flour folic acid fortification program reduces serum homocysteine levels and masks vitamin B-12 deficiency in elderly people. J Nutr 2002;132:289-91.

66. Nazer J, Aguila A, Cifuentes L. La frecuencia de nacimientos de gemelos aumentó en un hospital chileno coincidiendo con el consumo periconcepcional de harina fortificada con ácido fólico. Rev Méd Chile 2006; 134:48-52.

67. Wald NJ, Law MR, Morris JK, Wald DS. Quantifying the effect of folic acid. Lancet 2001; 358:2069-73.

68. Choumenkovitch SF, Selhub J, Wilson PW, Rader JI, Rosenberg IH, Jacques PF. Folic acid intake from fortification in United States exceeds predictions. J Nutr 2002; 132:2792-8.

69. Jacques PF, Selhub J, Bostom AG, Wilson PW, Rosenberg IH. The effect of folic acid fortification on plasma folate and total homocysteine concentrations. N Engl J Med 1999; 340:1449-54.

70. Pfeiffer CM, Johnson CL, Jain RB, Yetley EA, Picciano MF, Rader JI, et al. Trends in blood folate and vitamin B-12 concentrations in the United States, 1988-2004. Am J Clin Nutr 2007; 86:718-27.

71. Quinlivan EP, Gregory 3rd JF. Reassessing folic acid consumption patterns in the United States (1999 2004): potential effect on neural tube defects and overexposure to folate. Am J Clin Nutr 2007; 86:1773-9.

72. Hickling S, Hung J, Knuiman M, Jamrozik K, McQuillan B, Beilby J, et al. Impact of voluntary folate fortification on plasma homocysteine and serum folate in Australia from 1995 to 2001: a population based cohort study. J Epidemiol Community Health 2005; 59:371-6.

73. Persad VL, Van den Hof MC, Dubé JM, Zimmer P. Incidence of open neural tube defects in Nova Scotia after folic acid fortification. CMAJ 2002; 167:241-5

74. Liu S, West R, Randell E, Longerich L, O'Connor KS, Scott H, et al. A comprehensive evaluation of food fortification with folic acid for the primary prevention of neural tube defects. BMC Pregnancy Childbirth 2004; 4:20.

75. Molloy AM, Kirke PN, Troendle JF, Burke H, Sutton M, Brody LC, et al. Maternal vitamin B12 status and risk of neural tube defects in a population with high neural tube defect prevalence and no folic acid fortification. Pediatrics 2009; 123:917-23.

76. Agência Nacional de Vigilância Sanitária. RDC no 344, de 13 de dezembro de 2002. Aprova o regulamento técnico para a fortificação das farinhas de trigo e milho com ferro e ácido fólico. http://e-le gis.anvisa.gov.br/legis/resol/2002/344_02rdc.htm (accessed on 30/Jun/2008).

77. Instituto Nacional de Metrologia, Normalização e Qualidade Industrial. Produtos de festa junina amendoim, fubá de milho e leite de coco. http:// www.inmetro.gov.br/consumidor/produtos/festa Junina.asp (accessed on 26/Jun/2005).

78. Soeiro BT, Boen TR, Wagner R, Lima-Pallone JA Physico-chemical quality and homogeneity of folic acid and iron in enriched flour using principal component analysis. Int J Food Sci Nutr 2009; 27:1-13.
79. Pacheco SS, Braga C, Souza AI, Figueiroa JN. Efeito da fortificação alimentar com ácido fólico na prevalência de defeitos do tubo neural. Rev Saúde Pública 2009; 43:565-71.

80. Castilla EE, Orioli IM, Lopez-Camelo JS, Dutra MG, Nazer-Herrera J; Latin American Collaborative Study of Congenital Malformations. Preliminary data on changes in neural tube defect prevalence rates after folic acid fortification in South America. Am J Med Genet A 2003; 123A:123-8.

81. Flynn MA, Anderson WA, Burke SJ, Reilly A. Session 1: public health nutrition. Folic acid food fortification: the Irish experience. Proc Nutr Soc 2008; 67:381-9.

82. World Health Organization. Guidelines on food fortification with micronutrients. Geneva: World Health Organization; 2006.

83. Instituto Brasileiro de Geografia e Estatística. Pesquisa de Orçamentos Familiares (POF) 2002-2003: aquisição alimentar domiciliar per capita. Rio de Janeiro: Instituto Brasileiro de Geografia e Estatística; 2004.

84. Fletcher RJ, Bell IP, Lambert JP. Public health aspects of food fortification: a question of balance. Proc Nutr Soc 2004; 63:605-14.

85. Sudha ML, Leelavathi K. Influence of micronutrients on rheological characteristics and breadmaking quality of flour. Int J Food Sci Nutr 2008; 59:105-15

86. Rosado JL, Camacho Solís R, Bourges H. Adición de vitaminas y minerales a harinas de maíz y de trigo en México. Salud Pública Méx 1999; 41:130-7.

87. Wright AJ, Dainty JR, Finglas PM. Folic acid metabolism in human subjects revisited: potential implications for proposed mandatory folic acid fortification in the UK. Br J Nutr 2007; 98:667-75.

88. Powers HJ. Folic acid under scrutiny. Br J Nutr 2007; 98:665-6.

89. Troen AM, Mitchell B, Sorensen B, Wener MH, Johnston A, Wood B, et al. Unmetabolized folic acid in plasma is associated with reduced natural killer cell cytotoxicity among postmenopausal women. J Nutr 2006; 136:189-94.

90. Kelly P, McPartlin J, Goggins M, Weir DG, Scott JM. Unmetabolized folic acid in serum: acute studies in subjects consuming fortified food and supplements. Am J Clin Nutr 1997; 65:1790-5.

91. Bailey SW, Ayling JE. The extremely slow and variable activity of dihydrofolate reductase in human liver and its implications for high folic acid intake. Proc Natl Acad Sci U S A 2009; 106:15424-9.

92. Ashokkumar B, Mohammed ZM, Vaziri ND. Effect of folate oversupplementation on folate uptake by human intestinal and renal epithelial cells. Am J Clin Nutr 2007; 86:159-66.

93. Markle HV. Unmetabolized folic acid and masking of cobalamin deficiency. Am J Clin Nutr 1997; 66:1480-1.

94. Ericson U, Sonestedt E, Gullberg B, Olsson H, Wirfält E. High folate intake is associated with lower breast cancer incidence in postmenopausal women in the Malmö Diet and Cancer cohort. Am J Clin Nutr 2007; 86:434-43. 
95. Stolzenberg-Solomon RZ, Chang SC, Leitzmann MF, Johnson KA, Johnson C, Buys SS, et al. Folate intake, alcohol use, and postmenopausal breast cancer risk in the Prostate, Lung, Colorectal, and Ovarian Cancer Screening Trial. Am J Clin Nutr 2006; 83:895-904.

96. Cole BF, Baron JA, Sandler RS, Haile RW, Ahnen DJ, Bresalier RS, et al. Folic acid for the prevention of colorectal adenomas: a randomized clinical trial. JAMA 2007; 297:2351-9.

97. Lladó V, Terés S, Higuera M, Alvarez R, NogueraSalva MA, Halver JE, et al. Pivotal role of dihydrofolate reductase knockdown in the anticancer activity of 2-hydroxyoleic acid. Proc Natl Acad Sci U S A 2009; 106:13754-8.

98. Basten GP, Duthie SJ, Pirie L, Vaughan N, Hill MH, Powers HJ. Sensitivity of markers of DNA stability and DNA repair activity to folate supplementation in healthy volunteers. Br J Cancer 2006; 94:1942-7.

99. Mills JL. Fortification of foods with folic acid: how much is enough? N Engl J Med 2000; 342:1442-5.
100. Morris MS, Jacques PF, Rosenberg IH, Selhub J. Folate and vitamin B-12 status in relation to anemia, macrocytosis, and cognitive impairment in older Americans in the age of folic acid fortification. Am J Clin Nutr 2007; 85:193-200.

101. Kondo A, Kamihira O, Shimosuka Y, Okai I, Gotoh M, Ozawa H. Awareness of the role of folic acid, dietary folate intake and plasma folate concentration in Japan. J Obstet Gynaecol Res 2005; 31:172-7.

102. Wharton B, Booth I. Fortification of flour with folic acid. BMJ 2001; 323:1198-9.

103. Eichholzer M, Tönz O, Zimmermann R. Folic acid: a public-health challenge. Lancet 2006; 367: 1352-61.

Submitted on 10/Aug/2009

Final version resubmitted on 26/Mar/2010

Approved on 28/Sep/2010 